\title{
PERBANDINGAN APLIKASI PUPUK ORGANIK LIMBAH RUMAH TANGGA DAN FASES SAPI (Bos taurus) DENGAN PUPUK KIMIA
}

\author{
Trisnawati Nengseh ${ }^{1}$, Emi Jayanti ${ }^{2}$, Denaya Andrya Prasidya ${ }^{3}$ \\ ${ }^{1,2}$ Mahasiswa Program Studi Kesehatan Lingkungan Universitas Islam Lamongan \\ ${ }^{3}$ Dosen Program Studi Kesehatan Lingkungan Universitas Islam Lamongan \\ Email : \\ trisnawatinengseh@gmail.com \\ emijayantidp23@gmail.com \\ denayaandryaprasidya@gmail.com
}

\begin{abstract}
Livestock business has prospects to be developed because of the high demand for livestock products. So far, cow dung in the petiyen village has only been cleaned and thrown away for nothing without further use. One alternative to overcome this problem is to utilize cow manure as organic fertilizer. In addition to the waste generated from cows in general the petiyen community also produces waste from its household activities. Of the 2 types of organic waste in the form of cow waste and household waste will be processed into organic fertilizer which will be applied to rice and corn plants that are widely grown by farmers in Petiyen Village, Solokuro Subdistrict, Lamongan Regency. The purpose of this study was to determine the effect of the use of organic fertilizer on plant growth. This research method is experimental. The results showed that the average plant height was $13 \mathrm{~cm}$ for the use of organic fertilizer media only and $12 \mathrm{~cm}$ for mixed organic fertilizer and soil media, while for chemical fertilizer media could not grow. Root length on day 9, which uses $13 \mathrm{~cm}$ organic fertilizer media and which uses a mixture of organic fertilizer and $10 \mathrm{~cm}$ soil. it can be concluded that organic fertilizer affects the growth of green bean plants
\end{abstract}

Key Word: Organic Fertilizer, Hosehold Waste, Cow Dung

\section{PENDAHULUAN}

Usaha peternakan mempunyai prospek untuk dikembangkan karena tingginya permintaan akan produk peternakan, contohnya di desa Petiyen Kecamatan Solokuro Kabupaten Lamongan merupakan sebuah desa yang sebagian besar penduduknya adalah terdiri dari peternak dan petani. Salah satunya adalah peternak sapi. usaha peternakan sapi sendiri bukanlah sebuah usaha ternak yang menjanjikan dengan modal kecil dan menguntungkan dalam waktu yang singkat, memerlukan ekstra kesabaran dan modal yang cukup untuk bisa melakukan pembibitan, perawatan (pemberian pakan kepada hewan dan perawatan kandang), dan strategi bisnis ternak yang mumpuni. Kelebihan sapi adalah dagingnya yang dapat dimanfaatkan untuk di konsumsi, kulitnya yg dapat di buat beduk masjid, dan mudah beradaptasi dengan lingkungan, sedangkan kekurangan sapi adalah Limbah kotoran yang aromanya selama ini menganggu warga sekitar. Sejauh ini kotoran sapi di desa petiyen hanya di bersihkan dan dibuang percuma tanpa ada pemanfaatan lebih lanjut. Salah satu alternatif untuk mengatasi masalah tersebut adalah dengan memanfaatkan limbah kotoran sapi sebagai pupuk organik. Selain limbah yang dihasilkan dari sapi secara umum masyarakat petiyen juga menghasilkan limbah dari aktifitas rumah tangganya.

Limbah rumah tangga merupakan bahan sisa yang dihasilkan dari kegiatan rumah tangga. Jenis sampah yang berasal dari segala jenis kegiatan di rumah tangga biasanya berupa sisa pengolahan makanan, perlengkapan rumah bekas, kertas, kardus, gelas, kain, sampah dari kebun dan halaman, dan masih banyak lagi. Limbah yang berasal dari sisa-sisa makanan dapat diolah kembali menjadi pupuk, tetapi sejauh ini masyarakat daerah petiyen kecamatan solokuro kabupaten lamongan hanya membuang dan membakar sampah tersebut, dampak dari pembuangan sampah sembarangan dapat merusak pemandangan, mendatangkan bau yang tidak sedap, mendatangkan banjir level rendah sampai yang tinggi, mendatangkan berbagai penyakit dan dapat mencemari lingkungan. 


\section{Vol. 3 No. 1 Maret 2019}

Apalagi jika sampah tersebut dibakar maka akan menyebabkan polusi udara karena menimbulkan debu dan asap hitam yang mengganggu. Sampah yang dibakar juga melepaskan karbondioksida (CO2) yang justru akan memperparah pemanasan global. Selain itu gas chlor yang dihasilkan dari pembakaran sampah juga dapat merusak atmosfer bumi.

Dari 2 jenis limbah organik yang ada di antaranya limbah fases sapi dan limbah sampah rumah tangga akan kami olah menjadi pupuk organik. Pupuk organik adalah pupuk yang dapat mengalami pelapukan oleh sisa-sisa mahluk hidup atau tumbuhan, pupuk organik bisa berbentuk padat maupun cair yang berguna untukmemperbaiki sifat fisik, kimia dan biologi tanah.pupuk organik memiliki sedikit kadar haranya dan mengandung banyak bahan organik. Sumber bahan organik dapat berupa kompos, pupuk hijau, pupuk kandang, sisa panen, limbah ternak, limbah industri yang menggunakan bahan pertanian, dan limbah kota (sampah). Kedepannya pupuk organik tersebut akan di aplikasikan pada tanaman padi dan jagung yang banyak ditanam oleh petani-petani yang ada di desa petiyen kecamatan solokuro kabupaten lamongan.

Dari latar belakang di atas maka kami melakukan penelitian dengan judul "Perbandingan Aplikasi Pupuk Organik Limbah Rumah Tangga dan Fases Sapi dengan Pupuk Kimia."

\section{METODE PENELITIAN}

Penelitian ini menggunakan metode eksperimen, metode eksperimen adalah prosedur penelitian yang dilakukan untuk mengungkapkan hubungan sebab akibat dua variabel atau lebih, dengan mengendalikan pengaruh variabel yang lain. Metode ini dilaksanakan dengan memberikan variabel bebas secara sengaja (bersifat induse) kepada objek penelitian untuk diketahui akibatnya di dalam variabel terikat. (Zulnaidi ;2007)

\section{Waktu dan Tempat}

Waktu dan tempat penelitian di laksanakan pada:

Tanggal : 13 April 2019 - 09 Juni 2019

Lokasi : KSM Kendal Kemlagi Kec. Kalitengah Kab. Lamongan

\section{Alat dan Bahan}

\begin{tabular}{|l|l|l|}
\hline No & \multicolumn{1}{|c|}{ Alat } & \multicolumn{1}{c|}{ Bahan } \\
\hline 1 & Sekop & Fases Sapi \\
\hline 2 & Ember & $\begin{array}{l}\text { Limbah Organik } \\
\text { Rumah Tangga }\end{array}$ \\
\hline 3 & Kresek & Molase \\
\hline 4 & Sendok & Air \\
\hline
\end{tabular}

\begin{tabular}{|l|ll|l|}
\hline & Makan & \\
\hline 5 & $\begin{array}{l}\text { Gelas Air } \\
\text { Mineral }\end{array}$ & EM-4 & \\
\hline & & $\begin{array}{l}\text { Biji C Kacang } \\
\text { Hijau }\end{array}$ & \\
\hline
\end{tabular}

\section{Rancangan Penelitian}

\section{Cara Pembuatan Pupuk:}

1. Mengumpulkan feses sapi

2. Mengumpulkan limbah rumah tangga ( organic )

3. Pencacahan limbah rumah tangga

4. Mencampurkan feses sapid an limbah rumah tangga menjadi satu

5. Mencampurkan air, gula dan EM4

6. Menyiram campuran feses sapid an limbah rumah tangga dengan campuran air, EM4 dan molase

7. Menutup dengan terpal selama kurang lebih 3 minggu

8. Pupuk yang sudah jadi di aplikasikan pada tanaman

Aplikasi Pupuk Terhadap Tanaman Kacan Hijau

Perlakuan 1 (Pupuk Organik)
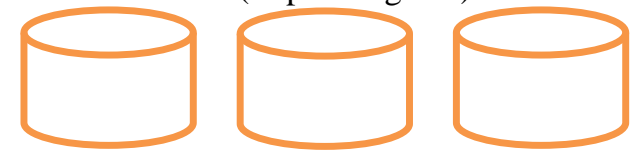

Pelakuan 2 (Pupuk Kimia)
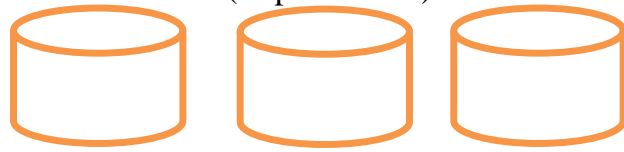

Pelakuan 3 (Tanah)
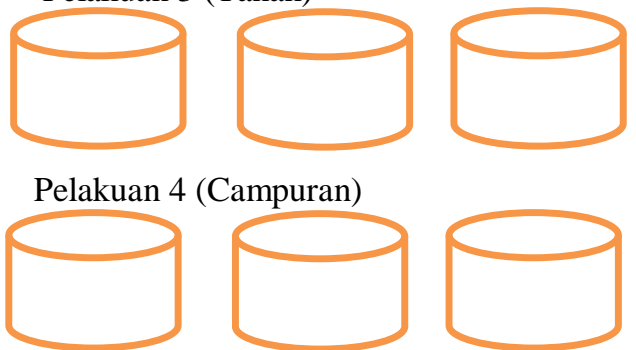

Metode Pengumpulan data

1. Perbedaan Fisik Pupuk. Perbedaan fisik yang diamati meliputi bentuk, warna, kepadatan, dan bau

2. Pertumbuhan Tanaman. Melihat pertumbuhan yang meliputi warna daun, panjang akar, tinggi tanaman, dan jumlah daun.

\section{Hasil dan Pembahasan}

Hasil

1. Laju pertumbuan tinggi batang pada tanaman 


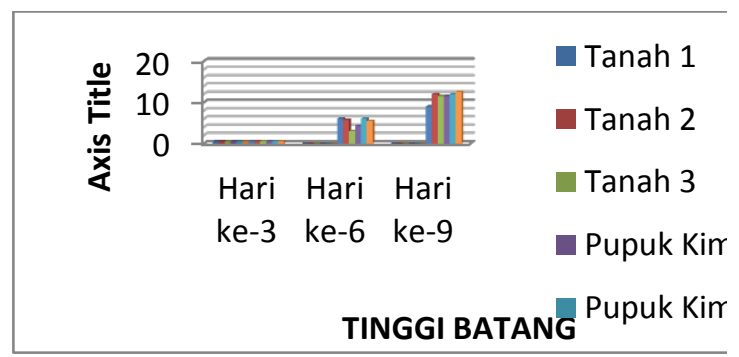

Grafik 1. Laju pertumbuan tinggi batang pada tanaman

Seperti yang terlihat pada grafik 1 . Hari ke tiga penanaman kacang hijau diketahui baru tumbuh sehingga tidak dapat diukur secara pasti, di hari ke enam semua media mati kecuali pupuk organik dan campuran, dan hari ke sembilan tanaman yang medianya pupuk organik lebih tinggi dari pada tanaman dengan media campuran.

2. Laju pertumbuan panjang akar pada tanaman

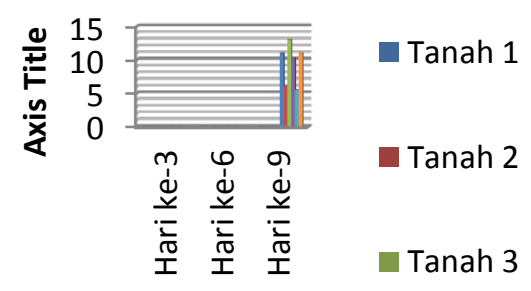

\section{PANJANG AKAR}

Grafik 2. Laju pertumbuan panjang akar pada tanaman

Pada grafik 2 dijelaskan bahwa Panjang akar baru bisa diukur pada hari ke sembilan di karenakan pengukurannya dengan cara mencabut tanaman tersebut. Di hari ke sembilan yang dapat bertahan hidup hanya tanaman dengan media pupuk organik dan media campuran, sehingga di dapatkan hasil media campuran lebih panjang akarnya dibanding media pupuk organik.

3. Laju jumlah daun pada tanaman

\begin{tabular}{|c|c|c|}
\hline \multirow[t]{3}{*}{ 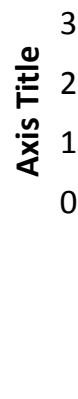 } & 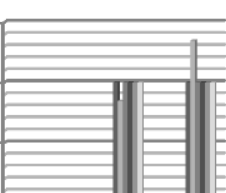 & $\begin{array}{l}\text { - Tanah } 1 \\
\text { - Tanah } 2\end{array}$ \\
\hline & $\begin{array}{l}\text { Hari Hari Hari } \\
\text { ke-3 ke-6 ke-9 }\end{array}$ & Tanah 3 \\
\hline & JUMLA & AUN \\
\hline
\end{tabular}

Grafik 3. Laju jumlah daun pada tanaman

Pada grafik 3 dijelaskan Jumlah daun di hari ketiga tidak dapat di ketahui di karenakan tanaman baru tumbuh kuncup, di hari ke enam hanya media pupuk organik dan media campuran yang dapat bertahan hidup dan didapat rata-rata terendah adalah campuran 2 yaitu 1,7, dan di hari kesembilan rata-rata tertinggi adalah campuran 2 yaitu 2,7.

4. Warna Daun pada tanaman

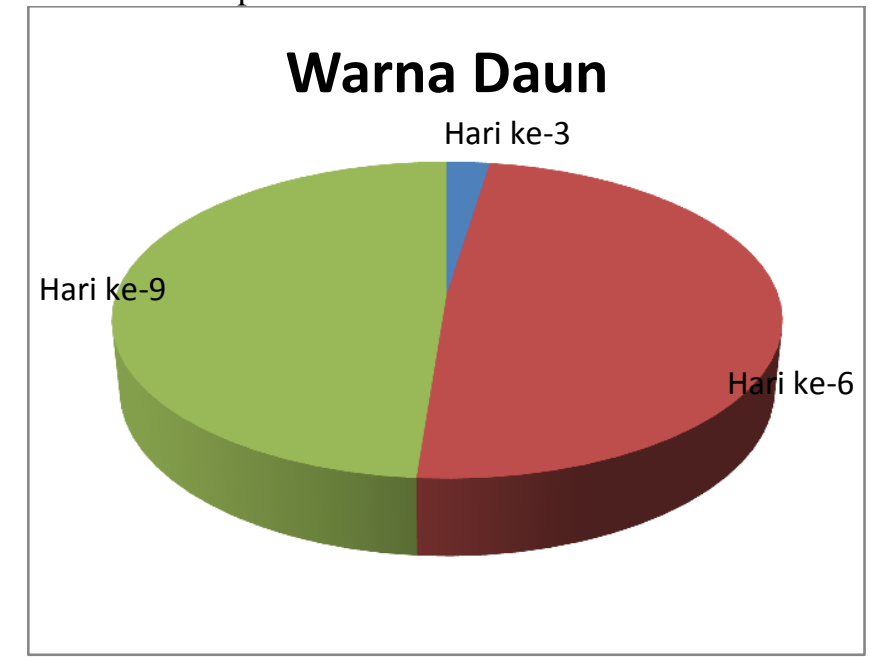

Grafik 5. Warna Daun pada tanaman

Di hari ke tiga hanya sebagian daun yang sudah terlihat warna daunnya yaitu berwarna hijau pupus, di karenakan tanaman masih kuncup. Di hari ke enam semua tanaman yang tumbuh daunnya berwarna hijau muda, dan di hari kesembilan semua daun tanaman berwarna hijau tua.

\section{HASIL DAN PEMBAHASAN}

Berdasarkan dari hasil penelitian diatas untuk mendapatkan hasil pupuk organik yang baik adalah dengan melihat perubahannya terutama pada warna, semakin hitam warna pupuk kompos bertandakan siap untuk digunakan. Dilihat dari data hasil praktikum, tersebut mengalami pembusukan dengan menunjukan perubahan warna hitam.

Selain perubahan warna perubahan juga terjadi terhadap aroma pada pupuk organik, pupuk organik yang siap digunakan akan mengeluarkan aroma kurang sedap, peristiwa ini dapat diketahui bahwa puppuk organik ini diuraikan oleh bakteri-bakteri penghasil sulfur yaitu jenis bakteri anaerob yang juga selama proses pengomposanpun wadah dibiarkan tertutup tanpa oksigen, Dari beberapa kondisi yang terlihat, pengomposan tanpa udara/anaerob memacu bakteri-bakteri yang suka tanpa oksigen untuk menguraikan substrat ini dan kerja bakteri suka oksigen terhambat akibatnya bakteri anaerobik ini yang mendominasi dan mereduksi senyawa-senyawa khas beraroma tak sedap. Dari segi ukuran antara sebelum pengkomposan dengan yang sudah terlihat perubahan, ini yang mengakibatkan proses pengkomposan terlaksana.

Dari percobaan tersebut dapat di lakukan untuk mengetahui pengaruh nutrisi terhadap pertumbuhan dan perkembangan 


\section{Jurnal EnviScience (Environment Science) Vol. 3 No. 1 Maret 2019}

kacang hijau (Vigna radiata) dapat diketahui bahwa pada perkecambahan kacang hijau dengan pemberian jenis media pada masingmasing gelas menunjukan hasil yang berbeda.

Biji kacang hujau pada masing-masing media diberi pupuk yang berbeda-beda namun dengan takaran yang sama, pupuk yang digunakan antara lain pupuk organik dan pupuk kimia. Dari keempat pengamatan diatas mendapatkan hasil yang berbeda dari setiap wadah yang berisi tanah, pupuk kimia, campuran, dan pupuk organik.

Aplikasi pupuk organik pada tanah yang miskin C-organik dan $\mathrm{N}$-total dapat meningkatkan hasil panen tebu (Sudiarto dkk; 2002)

\section{Kesimpulan}

Dari percobaan diatas semua media dan semua gelas mendapatkan hasil yang sama pada hari ketiga, namun pada hari keenam terjadi perubahan pada media pupuk kimia dan media tanah disemua gelas, semua tanaman pada media pupuk kimia mati setelah pengaplikasian pupuk kimia yang dilakukan dihari ketiga dan pada hari kesembilan semua media dapat bertahan serta tumbuh dengan normal kecuali media pupuk kimia dan media tanah.

Dari hasil di atas dapat dilihat bahwa pertumbuhan pada tanaman kacang hijau dengan media pupuk organik dan campuran (tanah dan pupuk organik) lebih cepat daripada tanaman kacang hijau yang diberi pupuk NPK maupun tanpa pupuk meskipun tidak ada perubahan yang signifikan dikarenakan faktor suhu, udara maupun media tanamnya kurang

DAFTAR PUSTAKA

Biblembang. 2019. Ladang Emas Dibalik Kotoran Sapi. http://biblembang.ditjenpkh.pe rtanian.go.id/read/584/ladangemas-dibalik-kotoran-sapi. Diakses 26 Maret 2019.

Fatmawati Umi. 2010. Potensi Kotoran Sapi. https://umifatmawati.blog.uns. ac.id/2010/03/25/potensi-

kotoran-sapi/. Diakses 26 Maret 2019.

Frobel G. Dewanto dkk. 2013. "Pengaruh Pemupukan Anorganik dan Organik Terhadap Produksi Tanaman Jagung Sebagai Sumber Pakan". Jurnal Zootek Volume 32 no. 05. ISSN 08522626.
Gen. 2013. Pupuk Organik Hayati. http://pupukorganik.co/pupukorganik/. Diakses 26 Maret 2019.

Green Planet. 2015. Pengertian Pupuk Organik. http://www.greenplanet.co.id/i ndex.php/post/69/Pengertian+ Pupuk+Organik. Diakses 21 Juni 2019.

Lisnawati. 2012. Pertanian Organik. http://lisnawatiharyadi.blogsp ot.com/2012/11/pupukorganik.html. Diakses 26 Maret 2019.

Melisa Kusumawati. 2017. Sapi. http://www.kerjanya.net/faq/1 8006-sapi.html. Diakses 26 Maret 2019.

Peternak Ganteng. 2017. Kelebihan dan Kekurangan Sapi Potong. https://agribisnisternakrumina nsiaweb.wordpress.com/2017/ 01/12/kelebihan-dankekurangan-sapi-potong/. Diakses 21 Juni 2019.

Ragam organisme. 2012. Mengenal Hewan dan Tumbuhan. http://ragamorganisme.blogsp ot.com/2012/07/sapi.html. Diakses 26 Maret 2019

Sudiarto dkk. 2002. "Pengaruh Pupuk Organik “. Jurnal Penelitian Tanaman Industri Volume 8 no. 3 Tahun 2002. ISSN 0853-8212.

Yatim. 2019. Macam-macam Limbah Lengkap. https://thegorbalsla.com/limba h/. Diakses 26 Maret 2019.

Yuliana. 2014. Limbah Rumah Tangga. https://yulianaputrisari.wordpr ess.com/2014/05/18/limbahrumah-tangga/. Diakses 21 Juni 2019. 